\title{
Design and Synthesis of Novel Epidermal Growth Factor Receptor Kinase Inhibitors
}

\author{
Jae Du Ha, ${ }^{*}$ Seung Kyu Kang, Kun-Do Kim, ${ }^{\dagger}$ Joong-Kwon Choi, Jae Yang Kong, and Chang H. Ahn \\ Medicinal Science Division, Korea Research Institute of Chemical Technology, Daejeon 305-600, Korea \\ *E-mail: jdha@krict.re.kr \\ ${ }^{\dagger}$ Department of Microbiology, Pukyong National University, Pusan 608-737, Korea \\ ${ }^{\star}$ Rexahn Corporation, 9620 Medical Center Dr., Rockville, MD20850, USA \\ Received December 28, 2004
}

\begin{abstract}
Investigation of structure-activity relationships of novel quinazolines has identified 7,8-dihydro-[1,4]dioxino[2,3-g]quinazolines as a potent inhibitor of EGFR. These compounds have a benzodioxane framwork, which was prepared by regioselective $O$-alkylation of ethyl 3,4-dihydroxy benzoate by epoxide ring opening. Compounds 3f and 3k were more potent than ZD-1839 in EGF enzyme and EGFR autophosporylation inhibition assays.
\end{abstract}

Key Words : Cancer, EGFR, Tyrosine kinase, Quinazoline, Autophosphorylation assay

\section{Introduction}

Epidermal growth factor receptor (EGFR) is involved in signaling pathways controlling cell growth and differentiation. ${ }^{1}$ Increased EGFR expression and activity are closely related with an increase in tumor malignancy. ${ }^{2}$ Therefore, inhibitors of EGFR kinase activity may prove useful for therapeutic intervention in cancer as well as other proliferative diseases. The various 4 -anilinoquinazoline derivatives ${ }^{3}$ have been developed as a potent and selective inhibitor against various tyrosine kinase families, such as EGFR, VEGFR, and Src. However, 4-anilinoquinazoline $\mathbf{1}^{\text {3a-c }}$ having dimethoxy group at C-6 and C-7 suffered from poor bioavailability in vivo because of their low water solubility. In order to improve the pharmacokinetic properties of compounds, a number of laboratories have extensively tried to replace the methoxy groups at C-6 or C-7 with a variety of aminoalkoxy groups, resulting in much improved bioavailability. For example, ZD-1839 (2), ${ }^{4}$ having morpholino propoxy substituent at C-6 and methoxy group at C-7, is an orally active, potent, and selective EGFR inhibitor used in the clinic in the chemotherapy of non-small-cell lung cancer (NSCLC). ${ }^{5}$ From this consideration, further increase of<smiles>COc1cc2ncnc(Nc3cccc(Br)c3)c2cc1OCCCN1CCOCC1</smiles>
1 2<smiles>[R][R]1ccc(Nc2ncnc3cc4c(cc23)OC(CCN([R2])[R2])CO4)cc1</smiles>

polarity at C-6 and (or) C-7 may enhance the physical properties of the compounds. With this in mind, we tried to find potent EGFR inhibitors and discovered novel compounds 3, which possess a [1,4]-dioxino quinazoline structure $^{6}$ linking the alkoxy side chains together, because their structural characteristic is considered to have better solubility than dialkoxyquinazoline derivatives.

\section{Results and Discussion}

For constructing the key skeleton, [1,4]-dioxino quinazoline, an efficient method for regioselective alkylation of catechol need to be devised. Although regioselective alkylation of catechols with alkyl halides has been well studied to date, ${ }^{7}$ there has been no report about regioselective alkylation via the ring opening of epoxides. ${ }^{8,9}$ Since monoalkylation of catechol with alkyl halides under basic conditions takes place favorably at electron deficient hydroxyl group, we anticipated that alkylation of $\mathbf{4}$ with epoxides also shows the same pattern as the reaction with alkyl halides. With this in mind, we investigated the alkylation on finding effective bases under conditions as shown in Table 1.

Various base systems, ${ }^{10}$ such as $\mathrm{K}_{2} \mathrm{CO}_{3}, \mathrm{Et}_{3} \mathrm{~N}$ and $\mathrm{NaOEt}$ were not effective for alkylation, however the use of $\mathrm{KF}$ and $\mathrm{CsF}$ (entry 1 and 3$)^{8 \mathrm{~b}}$ were effective to generate the monosubstituted product as $c a$. $4: 1$ mixtures in a favor of $\mathrm{C}-4$ substituted product, along with large amount of starting material (ca. 30\%). Although the reaction occurred in the regioselective manner, the yield was poor, giving the product in less than $30 \%$ yield. Decreasing the amount of CsF (entry 4) gave improved results in terms of the yield and regioselectivity $(42 \%, 7: 1$, respectively). Best result was obtained in the use of an excess amount of epoxide ( 2 eq), affording the products as $7: 1$ mixtures in $62 \%$ yield, along with small amount of dialkylated product $(<5 \%)$.

Since two regioisomers were not separated by column chromatography, the ratio of the regioisomers was deter- 
Table 1.
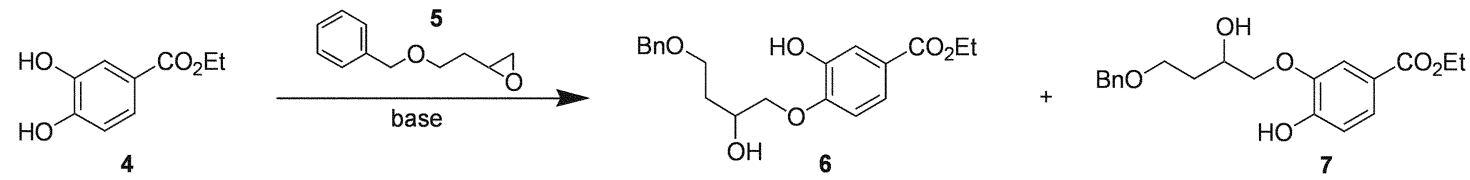

\begin{tabular}{ccccc}
\hline Entry & Base (eq.) & Conditions $^{a}$ & Yield (\%) $^{b}$ & Ratio (6/7) $^{b}$ \\
\hline 1 & $\mathrm{KF}(0.3)$ & $5 \mathrm{~h} / \mathrm{DMF} / \mathbf{5}$ & 23 & $5 / 1$ \\
2 & $\mathrm{CsF}(1.0)$ & $24 \mathrm{~h} / \mathrm{DMF} / \mathbf{5}$ & 21 & $5 / 1$ \\
3 & $\mathrm{CsF}(0.3)$ & $10 \mathrm{~h} / \mathrm{DMF} / \mathbf{5}$ & 29 & $5 / 1$ \\
4 & $\mathrm{CsF}(0.02)$ & $14 \mathrm{~h} / \mathrm{DMF} / \mathbf{5}$ & 42 & $7 / 1$ \\
5 & $\mathrm{CsF}(0.02)$ & $10 \mathrm{~h} / \mathrm{DMSO} / \mathbf{5}$ & 40 & $6 / 1$ \\
6 & $\mathrm{CsF}(0.02)$ & $8 \mathrm{~h} / \mathrm{NMP} / \mathbf{5}$ & - & $7 / 1$ \\
7 & $\mathrm{CsF}(0.02)$ & $15 \mathrm{~h} / \mathrm{DMF} / \mathbf{5}^{c}$ & 51 & $7 / 1$ \\
8 & $\mathrm{CsF}(0.02)$ & $15 \mathrm{~h} / \mathrm{DMF} / \mathbf{5}^{d}$ & 62 & $\mathbf{7}^{d}$ \\
\hline
\end{tabular}

${ }^{a} \mathbf{5}(1.1 \mathrm{eq}), 130{ }^{\circ} \mathrm{C} ;{ }^{b}$ isolated yield; ${ }^{c} 1.5$ eq.; ${ }^{d} 2$ eq.

mined by ${ }^{1} \mathrm{H}-\mathrm{NMR}$ analysis of regioisomeric mixtures after methylation of hydroxyl group of phenol. The unambiguous confirmation of structure was made by comparison of the product obtained by methylation of $\mathbf{6}$ and the product derived by methylation of a commercially available phenol 9 as described in Scheme 1. Ultimately, the desired regioisomer was obtained by crystallization of the nitro compound 11 prepared in 2 steps from the mixtures of $\mathbf{6}$ and 7.

In order to construct the requisite benzodioxane structure 6 was treated with diisopropyl azodicarboxylate and triphenylphosphine to give the desired benzodioxane $\mathbf{1 0}$ in $95 \%$ yield (Scheme 2 ).

The next step, nitration of $\mathbf{1 0}$, proved nontrivial. The nitration in usual condition $\left(60 \% \mathrm{HNO}_{3}, \mathrm{AcOH}, 50{ }^{\circ} \mathrm{C}\right)^{11}$ provided the desired product 11 in less than $38 \%$ yield, along with two side products, debenzylated product 12 and acetylated product 13 (16\% and $15 \%$, respectively). Although we were unable to improve the isolated yield beyond that reported here, the side products were readily converted to $\mathbf{1 1}$ by benzylation $(\mathrm{BnBr}, \mathrm{NaH})$ for $\mathbf{1 2}$, and by deacetylation and subsequent benzylation for 13. Reduction of $\mathbf{1 1}$ using Fe and $\mathrm{NH}_{4} \mathrm{Cl}$ gave the compound 14, which was readily converted by treatment with formamide and $\left(\mathrm{NH}_{4}\right)_{2} \mathrm{CO}_{3}$ to the 3,4-dihydroquinazoline-4-one 15. Chlorination of $\mathbf{1 5}$ $\left(\mathrm{SOCl}_{2}-\mathrm{DMF}\right)$ afforded the quinazoline 16. Scheme 3 outlines the synthesis of 4-anilino-[1,4]-dioxane quinazoline derivatives from 16. The treatment of $\mathbf{1 6}$ with anilines in isopropyl alcohol furnished the corresponding 17a-d. Removal of benzyl protecting group $\left(\mathrm{CF}_{3} \mathrm{CO}_{2} \mathrm{H}, 100{ }^{\circ} \mathrm{C}\right)$, followed by mesylation $\left(\mathrm{MsCl}, \mathrm{Et}_{3} \mathrm{~N}, 0{ }^{\circ} \mathrm{C}\right.$ ) and displace-<smiles>CCOC(=O)c1ccc(OCC(O)CCO)c(OCC)c1</smiles>

6<smiles>CCOC(=O)c1ccc(OCC(O)CCOCc2ccccc2)c(OC)c1</smiles>

8

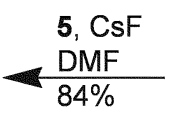

$\mathrm{HO}$<smiles>CCOC(=O)c1ccc(O)c(OC)c1</smiles>

Scheme 1<smiles>CCOC(=O)c1ccc(OCC(O)CCOc2ccccc2)c(O)c1</smiles><smiles>CCOC(=O)c1ccc2c(c1)OC(CCOCc1ccccc1)CO2</smiles><smiles>CCC</smiles><smiles>[R]OCCC1COc2cc([N+](=O)[O-])c(C(=O)OCC)cc2O1</smiles><smiles>CC(C)CCCCOCCC1COc2cc3ncnc(Cl)c3cc2O1</smiles>

16<smiles>O=c1[nH]cnc2cc3c(cc12)OC(CCOCc1ccccc1)CO3</smiles>

15<smiles>CCOC(=O)c1cc2c(cc1N)OCC(CCOCc1ccccc1)O2</smiles>

14

Scheme 2. (a) DIAD, TPP/benzene, r.t, $95 \%$ (b) $60 \% \mathrm{HNO}_{3}, \mathrm{AcOH}, 50{ }^{\circ} \mathrm{C}$; (c) $\mathrm{NaH}, \mathrm{BnBr} / \mathrm{THF}, 0{ }^{\circ} \mathrm{C}, 92 \%$; (d) $\mathrm{EtONa} / \mathrm{EtOH}$, r.t, $91 \%$; (e) $\mathrm{Fe}, \mathrm{NH}_{4} \mathrm{Cl} / \mathrm{MeOH}-\mathrm{H}_{2} \mathrm{O}$, reflux, $89 \%$; (f) $\mathrm{HCONH}_{2}$, ammonium carbonate, $180{ }^{\circ} \mathrm{C}$, $88 \%$; (g) $\mathrm{SOCl}_{2}-\mathrm{DMF}, 94 \%$ 
<smiles>Clc1ncnc2cc3c(cc12)OC(CCOc1ccccc1)CO3</smiles>

16<smiles>[R]c1ccc(Nc2ncnc3cc4c(cc23)OC(CCOCc2ccccc2)CO4)cc1</smiles>

17a: $R_{1}=3-C l$

$17 \mathrm{~b}: \mathrm{R}_{1}=3-\mathrm{Br}$

$17 \mathrm{c}: \mathrm{R}_{1}=3-\mathrm{Cl}, 4-\mathrm{F}$

$17 \mathrm{~d}: \mathrm{R}_{1}=2-\mathrm{F}, 4-\mathrm{Br}$<smiles>[R][R]1ccc(Nc2ncnc3cc4c(cc23)OC(CCO)CO4)cc1</smiles>

18a-d<smiles>[R][X]c1ccc(Nc2ncnc3cc4c(cc23)OC(CCN([R2])[R2])CO4)cc1</smiles>

3a-q

Scheme 3. (a) anilines, IPA, reflux, 68-82\%; (b) $\mathrm{BBr}_{3}$, reflux, 75-95\%; (c) (i) $\mathrm{MsCl}, \mathrm{Et}_{3} \mathrm{~N}, 0{ }^{\circ} \mathrm{C}$; (ii) amines, $\mathrm{KI}, 80^{\circ} \mathrm{C}$.

Table 2.

\begin{tabular}{|c|c|c|c|c|c|c|c|}
\hline Compounds & $\mathrm{R}_{1}$ & $\mathrm{R}_{2}$ & $\mathrm{IC}_{50}(\mathrm{nM})$ & Compounds & $\mathrm{R}_{1}$ & $\mathrm{R}_{2}$ & $\mathrm{IC}_{50}(\mathrm{nM})$ \\
\hline $3 \mathbf{a}$ & $4-\mathrm{Br}, 2-\mathrm{F}$ & $N$-methylpiperazine & 120 & $3 \mathbf{k}$ & $3-\mathrm{Cl}$ & morpholine & 22 \\
\hline $\mathbf{3 b}$ & $4-\mathrm{Br}, 2-\mathrm{F}$ & morpholine & 99 & 31 & $3-\mathrm{Cl}$ & piperidine & 58 \\
\hline $3 \mathbf{c}$ & $4-\mathrm{Br}, 2-\mathrm{F}$ & piperidine & 122 & $3 \mathrm{~m}$ & $3-\mathrm{Cl}$ & diethylamine & 66 \\
\hline 3d & $4-\mathrm{Br}, 2-\mathrm{F}$ & diethylamine & 120 & $3 n$ & $3-\mathrm{Cl}$ & pyrrolidine & 70 \\
\hline $3 e$ & $3-\mathrm{Br}$ & $N$-methylpiperazine & 36 & 30 & $3-\mathrm{Cl}, 4-\mathrm{F}$ & $N$-methylpiperazine & 72 \\
\hline $3 f$ & $3-\mathrm{Br}$ & morpholine & 42 & $3 p$ & $3-\mathrm{Cl}, 4-\mathrm{F}$ & morpholine & 66 \\
\hline $3 g$ & $3-\mathrm{Br}$ & piperidine & 52 & $3 q$ & $3-\mathrm{Cl}, 4-\mathrm{F}$ & piperidine & 66 \\
\hline $3 \mathbf{h}$ & $3-\mathrm{Br}$ & diethanolamine & 100 & $18 \mathrm{a}$ & $3-\mathrm{Cl}$ & $\mathrm{OH}$ & 52 \\
\hline $3 \mathbf{i}$ & $3-\mathrm{Br}$ & pyrrolidine & 62 & $18 \mathrm{~b}$ & $4-\mathrm{Br}, 2-\mathrm{F}$ & $\mathrm{OH}$ & 120 \\
\hline $3 \mathbf{j}$ & $3-\mathrm{Cl}$ & $N$-methylpiperazine & 64 & ZD-1839 & & & 56 \\
\hline
\end{tabular}

ment of mesylate by various amines afforded the compound 3a-q.

The compounds were tested for their in vitro inhibitory activity using the Alpha Screen ${ }^{\mathrm{TM}}$ P-Tyr-100 assay kit against EGF kinase. The results are given in $\mathrm{IC}_{50}$ values as shown in Table 2. In this assay, ZD-1839 was used as a reference and showed a potent inhibitory activity $\left(\mathrm{IC}_{50}=56\right.$ $\mathrm{nM}$ ) in our system.

Table 2 shows compounds derived by combination between 4 different anilines and various amine derivatives at $\mathrm{R}_{2}$. Activity of compounds largely depends on variation of

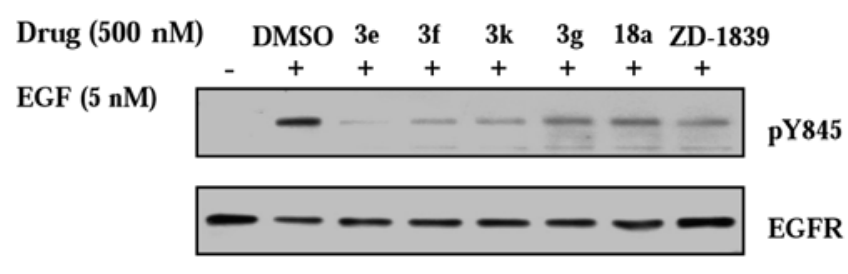

Figure 1. Effect of selective inhibitors on EGFR phosphorylation in A431 cells. Cells were harvested 10 min after addition of EGF (5 $\mathrm{nM}$ ). Cells were treated with $500 \mathrm{nM}$ of each compounds as indicated, 45 min before EGF addition. Equal amounts of protein were loaded in each lane. Blots were first probed with antibody against p-EGFR and then stripped, reprobed with antibody against total EGFR. the C-4 anilines, however, varying amine derivatives at $\mathrm{R}_{2}$ showed a minimal effect for in vitro activity. Compounds (3a-d) with 4-bromo-2-fluoro aniline were 2-fold less potent than ZD-1839. On the other hand, other anilines (e.g., 3bromo, 3-chloro, and 3-chloro-4-fluoro anilines) showed comparable enzyme activities, having $\mathrm{IC}_{50}$ values ranging from 22 to $72 \mathrm{nM}$, to that of ZD-1839, except for $\mathbf{3 h}$. Of those compounds, $\mathbf{3 e}$ and $\mathbf{3 k}$ were among the most potent in EGF enzyme assay, $\mathrm{IC}_{50}$ 's of $36 \mathrm{nM}$ and $22 \mathrm{nM}$, respectively. It is interesting that when the amino group at $\mathrm{R}_{2}$ was replaced with the hydroxy (18a), the activity was comparable to ZD-1839 in enzyme assay.

For inhibition studies of EGFR autophosphorylation ${ }^{11}$ for selective inhibitors, A431cells were incubated with $\mathbf{3 e}, \mathbf{3 f}$, $\mathbf{3 k}, \mathbf{3 g}$, and 18a at $500 \mathrm{nM}$ concentration and then stimulated with EGF. Each compound considerably inhibited autophosphorylation of EGFR in A431 cells, as shown by Western blot analysis (Figure 1).

For inhibition studies of EGFR autophosphorylation ${ }^{12}$ for selective inhibitors, A431cells were incubated with $3 \mathbf{e}, \mathbf{3 f}$, $\mathbf{3 k}, 3 \mathrm{~g}$, and 18a at $500 \mathrm{nM}$ concentration and then stimulated with EGF. Each compound considerably inhibited autophosphorylation of EGFR in A431 cells, as shown by Western blot analysis (Figure 1). The compounds $\mathbf{3 e}$ and $\mathbf{3 f}$ with 3-bromo aniline are much more potent than ZD-1839. 
On the other hand, 3k, having the most potent enzyme activity in these series, resulted in a similar inhibitory activity in autophosphorylation of EGFR compared to ZD1839. Interestingly, the $\mathrm{OH}$ compound (18a) at $\mathrm{R}_{2}$ retained their activity as shown in enzyme assay.

In summary, a new series of potent EGFR kinase inhibitors has been synthesized. Regioselective alkylation of catechol with epoxide using $\mathrm{CsF}$ as base can be rapidly accessable to $[1,4]$-dioxine intermediate, which was readily converted to $[1,4]$-dioxino quinazoline structure. The compounds $\mathbf{3 f}$ and $\mathbf{3 k}$ were more potent than ZD-1839 in EGF enzyme and EGFR autophosporylation inhibition assays.

\section{Experimental Sections}

4-(4-Benzyloxy-2-hydroxybutoxy)-3-hydroxybenzoic acid ethyl ester (6): To a solution of ethyl 3,4-dihydroxybenzoate 4 (7.5 g, $41 \mathrm{mmol})$ and $\mathrm{CsF}(0.14 \mathrm{~g}, 0.9 \mathrm{mmol})$ in DMF $(100 \mathrm{~mL})$ was added 2-(2-benzyloxyethyl)oxirane $\mathbf{5}$ $(7.3 \mathrm{~g}, 41 \mathrm{mmol})$, and the reaction mixture was stirred for $7 \mathrm{~h}$ at $130{ }^{\circ} \mathrm{C}$. After additional amount of 2-(2-benzyloxyethyl)oxirane 5 ( $7.3 \mathrm{~g}, 41 \mathrm{mmol})$ was added, the resulting mixture was stirred for $10 \mathrm{~h}$ at $130{ }^{\circ} \mathrm{C}$. Ethyl acetate and water were added and the organic layer was separated. The aqueous layer was extracted with EtOAc and the combined organic layers were washed with brine and dried over $\mathrm{MgSO}_{4}$, and concentrated in vacuo. The residue was purified by column chromatography ( $3: 1$ hexane-EtOAc) to afford an inseparable mixture of 6 and $7(7.1 \mathrm{~g}, 62 \%, 7: 1)$, along with a small amount of dialkylated product $(<5 \%)$. Spectral data for 6: ${ }^{1} \mathrm{H}-\mathrm{NMR}\left(300 \mathrm{MHz}, \mathrm{CDCl}_{3}\right) \delta 7.59(\mathrm{~d}, J=2.1$ $\mathrm{Hz}, 1 \mathrm{H}), 7.54(\mathrm{dd}, J=8.3,2.1 \mathrm{~Hz}, 1 \mathrm{H}), 7.25-7.37(\mathrm{~m}, 5 \mathrm{H})$, $6.82(\mathrm{~d}, J=8.3 \mathrm{~Hz}, 1 \mathrm{H}), 4.54(\mathrm{~s}, 2 \mathrm{H}), 4.32(\mathrm{q}, J=7.2 \mathrm{~Hz}$, $2 \mathrm{H}), 4.08-3.92(\mathrm{~m}, 3 \mathrm{H}), 3.76-3.69(\mathrm{~m}, 2 \mathrm{H}), 1.90-1.76(\mathrm{~m}$, 2H), 1.37 (t, $J=7.2 \mathrm{~Hz}, 3 \mathrm{H})$; MS-ESI $360\left(\mathrm{M}^{+}, 1\right), 179$ (5), $137(6), 91(100)$.

3-(2-Benzyloxyethyl)-2,3-dihydrobenzo[1,4]dioxine-6carboxylic acid ethyl ester (10): To a solution of a crude mixture of $6(8.5 \mathrm{~g}, 23.5 \mathrm{mmol})$ in benzene $(200 \mathrm{~mL})$ were added diisopropyldiazodicarboxylate (DIAD, $4.1 \mathrm{~mL}, 25.9$ mmol) and triphenylphosphine $(6.8 \mathrm{~g}, 25.9 \mathrm{mmol})$, and the resulting mixture was stirred for $4 \mathrm{~h}$ at room temperature. The mixture was concentrated, and the residue was purified by column chromatography ( $5: 1$ hexane-EtOAc) to give an inseparable benzodioxine mixture $(7.9 \mathrm{~g}, 98 \%)$. Spectral data for 10: ${ }^{1} \mathrm{H}-\mathrm{NMR}\left(300 \mathrm{MHz}, \mathrm{CDCl}_{3}\right) \delta 7.57-7.54(\mathrm{~m}$, 2H), 7.34-7.25 (m, 5H), $6.87(\mathrm{~d}, J=9.0 \mathrm{~Hz}, 1 \mathrm{H}), 4.53(\mathrm{~s}$, 2H), 4.31 (q, $J=6.9 \mathrm{~Hz}, 2 \mathrm{H}), 3.97$ (dd, $J=11.6,7.8 \mathrm{~Hz}$, $1 \mathrm{H}), 3.72-3.64(\mathrm{~m}, 2 \mathrm{H}), 1.98(\mathrm{~m}, 2 \mathrm{H}), 1.37(\mathrm{t}, J=6.9 \mathrm{~Hz}$, 3H); MS-ESI $342\left(\mathrm{M}^{+}, 6\right), 161$ (4), 91 (100).

3-(2-Benzyloxyethyl)-7-nitro-2,3-dihydrobenzo[1,4]dioxine-6-carboxylic acid (11): To a solution of benzodioxine 10 (4.2 $\mathrm{g}, 11.7 \mathrm{mmol})$ in acetic acid $(30 \mathrm{~mL})$ was added nitric acid (fuming, $10 \mathrm{~mL}$ ) and the mixture was stirred for 3 $\mathrm{h}$ at $50{ }^{\circ} \mathrm{C}$. After cooling, the reaction mixture was poured into ice water and extracted with EtOAc $(2 \times 50 \mathrm{~mL})$. The combined extracts were washed with water and aqueous saturated $\mathrm{NaHCO}_{3}$ solution, followed by brine, dried over $\mathrm{MgSO}_{4}$, and concentrated in vacuo. The residue was purified by column chromatography ( $3: 1$ hexane-EtOAc) to give the benzyl ether $11(38 \%)$, along with two side products 12 (16\%) and 13 (15\%). Spectral data for 11: ${ }^{1} \mathrm{H}-\mathrm{NMR}(300$ $\left.\mathrm{MHz}, \mathrm{CDCl}_{3}\right) \delta 7.48(\mathrm{~s}, 1 \mathrm{H}), 7.32-7.25(\mathrm{~m}, 5 \mathrm{H}), 7.13(\mathrm{~s}$, $1 \mathrm{H}), 4.53(\mathrm{~s}, 2 \mathrm{H}), 4.43-4.31(\mathrm{~m}, 2 \mathrm{H}), 4.33(\mathrm{q}, J=7.1 \mathrm{~Hz}$, 2H), 4.00-3.94 (m, 1H), 3.70-3.64 (m, 2H), $1.95(\mathrm{~m}, 1 \mathrm{H})$, $1.33(\mathrm{t}, J=7.1 \mathrm{~Hz}, 3 \mathrm{H})$. Transformations of $\mathbf{1 2}$ and $\mathbf{1 3}$ to 11 were followed as described below. To a solution of the acetate 13 in EtOH $(10 \mathrm{~mL})$ was added cat. NaOEt, and the reaction mixture was stirred for $2 \mathrm{~h}$ at room temperature. After evaporating the solvent, the residue was dissolved in EtOAc, washed with brine, dried over $\mathrm{MgSO}_{4}$. Concentration and purification by column chromatography $(3: 1$ hexane-EtOAc) gave the alcohol 12 (91\%): ${ }^{1} \mathrm{H}-\mathrm{NMR}(300$ $\left.\mathrm{MHz} \mathrm{CDCl}_{3}\right) \delta 7.48(\mathrm{~s}, 1 \mathrm{H}), 7.15(\mathrm{~s}, 1 \mathrm{H}), 4.47-4.39(\mathrm{~m}$, 2H), 4.33 (q, $J=7.1 \mathrm{~Hz}, 2 \mathrm{H}), 4.02(\mathrm{dd}, J=11.6,7.7 \mathrm{~Hz}$, 1H), 3.90-3.85 (m, 2H), 2.36 (brs, 1H), 1.91 (m, 2H), 1.34 (t, $J=7.1 \mathrm{~Hz}, 3 \mathrm{H})$; MS-ESI $297\left(\mathrm{M}^{+}, 10\right), 153$ (8), 71 (92), 43 (100). To a solution of the alcohol $12(1.0 \mathrm{~g}, 3.36 \mathrm{mmol})$ in THF $(30 \mathrm{~mL})$ were added benzyl bromide $(0.48 \mathrm{~mL}, 4.03$ $\mathrm{mmol})$ and tetrabutylammonium iodide $(0.12 \mathrm{~g}, 0.33 \mathrm{mmol})$. After $60 \% \mathrm{NaH}(0.16 \mathrm{~g}, 4.04 \mathrm{mmol})$ was added slowly at 0 ${ }^{\circ} \mathrm{C}$, the reaction mixture was stirred for $1 \mathrm{~h}$ at $0{ }^{\circ} \mathrm{C}$. The solution was quenched with addition of $\mathrm{EtOH}$ and diluted with EtOAc. The solution was washed with brine, dried over $\mathrm{MgSO}_{4}$, and concentrated. The residue was purified with column chromatography ( $3: 1$ hexane-EtOAc) to give the nitrobenzodioxine 11 (1.18 g, 91\%).

7-Amino-3-(2-benzyloxyethyl)-2,3-dihydrobenzo[1,4]dioxine-6-carboxylic acid ethyl ester (14): A suspension of $\mathrm{NH}_{4} \mathrm{Cl}(4 \mathrm{~g}, 73.8 \mathrm{mmol})$ and $\mathrm{Fe}(2.5 \mathrm{~g}, 44.8 \mathrm{mmol})$ in $\mathrm{MeOH}$ : $\mathrm{H}_{2} \mathrm{O}(2: 1,60 \mathrm{~mL})$ was heated at reflux for $15 \mathrm{~min}$. The nitrobenzodioxine $11(6.2 \mathrm{~g}, 16.0 \mathrm{mmol})$ was added, and the resulting mixture was heated at reflux for $3 \mathrm{~h}$. After cooling, the solid material was filtered and the filtrate was extracted with $\mathrm{CH}_{2} \mathrm{Cl}_{2}$. The combined extracts were washed with brine, dried over $\mathrm{Na}_{2} \mathrm{SO}_{4}$, and concentrated to give the aminobenzodioxine (4.7 g, 82\%): ${ }^{1} \mathrm{H}-\mathrm{NMR}$ (300 MHz, $\left.\mathrm{CDCl}_{3}\right) \delta 7.4-7.25(\mathrm{~m}, 6 \mathrm{H}), 6.13(\mathrm{~s}, 1 \mathrm{H}), 4.52(\mathrm{~s}, 2 \mathrm{H}), 4.40-$ $4.1(\mathrm{~m}, 5 \mathrm{H}), 3.89-3.71(\mathrm{~m}, 2 \mathrm{H}), 1.97-1.86(\mathrm{~m}, 2 \mathrm{H}), 1.39-1.3$ (m, 3H); MS-ESI 357 (M+ $\left.\mathrm{M}^{+}, 52\right), 196$ (32), 167 (13), 91 (100).

7-(2-Benzyloxyethyl)-7,8-dihydro-3H-[1,4]dioxino [2,3g]quinazolin-4-one (15): A solution of the aminobenzodioxine $14(2.2 \mathrm{~g}, 6.2 \mathrm{mmol})$ and ammonium carbonate $(0.99 \mathrm{~g}, 9.8 \mathrm{mmol})$ in formamide $(25 \mathrm{~mL})$ was heated at reflux for $3 \mathrm{~h}$. After cooling, water was added and the precipitate was filtered, washed with water, and dried in vacuo to give the dioxinoquinazoline $15(1.5 \mathrm{~g}, 72 \%)$ : ${ }^{1} \mathrm{H}-$ NMR (300 MHz, DMSO-d $\left.\mathrm{d}_{6}\right) \delta 11.83$ (brs, 1H), 7.95 (s, 1H), $7.45(\mathrm{~s}, 1 \mathrm{H}), 7.35-7.26(\mathrm{~m}, 5 \mathrm{H}), 7.09(\mathrm{~s}, 1 \mathrm{H}), 4.51(\mathrm{~s}, 2 \mathrm{H})$, 4.49-4.37 (m, 2H), 4.08 (dd, $J=11.7,7.7 \mathrm{~Hz}, 1 \mathrm{H}), 3.65$ (m, 2H), 1.94 (m, 2H); MS-ESI $338\left(\mathrm{M}^{+}, 6\right), 229$ (3), 202 (2), $174(1), 91(100)$.

7-(2-Benzyloxyethyl)-4-chloro-7,8-dihydro-[1,4]dioxino- 
[2,3-g]quinazoline (16): A solution of the quinazolin-4-one $15(0.9 \mathrm{~g}, 2.7 \mathrm{mmol})$ and $\mathrm{DMF}$ (2 drops) in $\mathrm{SOCl}_{2}(20 \mathrm{~mL})$ was heated at reflux for $2 \mathrm{~h}$. After cooling, the solvent was evaporated and the residue was dissolved with $\mathrm{CH}_{2} \mathrm{Cl}_{2}$, washed with aqueous sat. $\mathrm{NaHCO}_{3}$ solution $(3 \times 15 \mathrm{~mL})$, dried over $\mathrm{MgSO}_{4}$, and concentrated. The residue was purified by column chromatography ( $3: 1$ hexane-EtOAc) to give the 4-chloroquinazoline $16(0.7 \mathrm{~g}, 74 \%)$ : ${ }^{1} \mathrm{H}-\mathrm{NMR}$ (300 MHz, DMSO-d 6 ) $\delta 8.85(\mathrm{~s}, 1 \mathrm{H}), 7.51(\mathrm{~s}, 1 \mathrm{H}), 7.34-7.26(\mathrm{~m}$, $6 \mathrm{H}), 4.55-4.42(\mathrm{~m}, 2 \mathrm{H}), 4.50(\mathrm{~s}, 2 \mathrm{H}), 4.14(\mathrm{~d}, J=11.7,7.7$ $\mathrm{Hz}, 1 \mathrm{H}), 3.68-3.61(\mathrm{~m}, 2 \mathrm{H}), 1.99-1.90(\mathrm{~m}, 2 \mathrm{H})$; MS-ESI 356 $\left(\mathrm{M}^{+}, 2\right), 338$ (15), 174 (11), 91 (100).

[7-(2-Benzyloxyethyl)-7,8-dihydro-[1,4]dioxino[2,3-g]quinazolin-4-yl]-(3-chlorophenyl)-amine (17a): A solution of the 4-quinazoline $16(50 \mathrm{mg}, 0.14 \mathrm{mmol})$ and 3chlorophenylamine $(0.018 \mathrm{~mL}, 0.17 \mathrm{mmol})$ in 2-propanol (2 $\mathrm{mL}$ ) was heated at reflux for $3 \mathrm{~h}$. After cooling, the precipitate was filtered, washed with ether, and dried to give the 4-anilinoquinazoline 17a (42 mg, 68\%): ${ }^{1} \mathrm{H}-\mathrm{NMR}(300$ MHz, DMSO-d $\left.\mathrm{d}_{6}\right) \delta 11.0$ (brs, $\left.1 \mathrm{H}\right), 8.88(\mathrm{~s}, 1 \mathrm{H}), 8.38(\mathrm{~s}, 1 \mathrm{H})$, 7.94 (brs, 1H), $7.74(\mathrm{~d}, J=9.9 \mathrm{~Hz}, 1 \mathrm{H}), 7.52(\mathrm{t}, J=8.1 \mathrm{~Hz}$, $1 \mathrm{H}), 7.40-7.28(\mathrm{~m}, 7 \mathrm{H}), 4.63(\mathrm{~m}, 2 \mathrm{H}), 4.54(\mathrm{~s}, 2 \mathrm{H}), 4.24(\mathrm{dd}$, $J=11.7,7.8 \mathrm{~Hz}, 1 \mathrm{H}), 3.68(\mathrm{~m}, 2 \mathrm{H}), 2.07-1.97$ (m, 2H); MSESI $447\left(\mathrm{M}^{+}, 9\right), 354$ (1), 104 (2), 91 (100).

[7-(2-Benzyloxyethyl)-7,8-dihydro-[1,4]dioxino[2,3-g]quinazolin-4-yl]-(3-bromophenyl)-amine (17b): Yield: $71 \%$; ${ }^{1} \mathrm{H}-\mathrm{NMR}\left(300 \mathrm{MHz}, \mathrm{DMSO}-\mathrm{d}_{6}\right) \delta 10.9$ (brs, $1 \mathrm{H}$ ), 8.87 $(\mathrm{s}, 1 \mathrm{H}), 8.36(\mathrm{~s}, 1 \mathrm{H}), 8.07(\mathrm{~s}, 1 \mathrm{H}), 7.78(\mathrm{~d}, J=7.8 \mathrm{~Hz}, 1 \mathrm{H})$, $7.51-7.27(\mathrm{~m}, 8 \mathrm{H}), 4.63(\mathrm{~m}, 2 \mathrm{H}), 4.53(\mathrm{~s}, 2 \mathrm{H}), 4.23(\mathrm{dd}, J=$ 11.7, $7.8 \mathrm{~Hz}, 1 \mathrm{H}), 3.71-3.67(\mathrm{~m}, 2 \mathrm{H}), 2.06-1.96(\mathrm{~m}, 2 \mathrm{H})$; MS-ESI $492\left(\mathrm{M}^{+}, 0.2\right), 340$ (2), 291 (12), 220 (10), 164 (100).

[7-(2-Benzyloxyethyl)-7,8-dihydro-[1,4]dioxino [2,3-g]quinazolin-4-yl]-(3-chloro-4-fluorophenyl)-amine (17c): Yield: $82 \%$; ${ }^{1} \mathrm{H}-\mathrm{NMR}\left(300 \mathrm{MHz}, \mathrm{DMSO}-\mathrm{d}_{6}\right) \delta 11.0$ (brs, $1 \mathrm{H}), 8.88$ (s, 1H), 8.35 (s, 1H), 8.06 (dd, $J=6.6,2.7 \mathrm{~Hz}$, $1 \mathrm{H}), 7.74(\mathrm{~m}, 1 \mathrm{H}), 7.54(\mathrm{t}, J=9.0 \mathrm{~Hz}, 1 \mathrm{H}), 7.39-7.28(\mathrm{~m}$, $6 \mathrm{H}), 4.59(\mathrm{~m}, 2 \mathrm{H}), 4.50(\mathrm{~s}, 2 \mathrm{H}), 4.20(\mathrm{dd}, J=11.7,7.8 \mathrm{~Hz}$, $1 \mathrm{H}), 3.66(\mathrm{~m}, 2 \mathrm{H}), 2.05-1.91(\mathrm{~m}, 2 \mathrm{H})$; MS-ESI $465\left(\mathrm{M}^{+}, 6\right)$, 274 (1), 157 (2), 91 (100).

[7-(2-Benzyloxyethyl)-7,8-dihydro-[1,4]dioxino[2,3-g]quinazolin-4-yl]-(2-bromo-4-fluorophenyl)-amine (17d): Yield: $68 \%$; ${ }^{1} \mathrm{H}-\mathrm{NMR}\left(300 \mathrm{MHz}, \mathrm{DMSO}-\mathrm{d}_{6}\right) \delta 11.3$ (brs, $1 \mathrm{H}), 8.79(\mathrm{~s}, 1 \mathrm{H}), 8.31(\mathrm{~s}, 1 \mathrm{H}), 7.77(\mathrm{~d}, J=9.9 \mathrm{~Hz}, 1 \mathrm{H})$, 7.49-7.40 (m, 2H), $7.31(\mathrm{~m}, 5 \mathrm{H}), 7.29(\mathrm{~m}, 1 \mathrm{H}), 4.59(\mathrm{~m}, 2 \mathrm{H})$, $4.53(\mathrm{~s}, 2 \mathrm{H}), 4.25(\mathrm{dd}, J=11.7,7.8 \mathrm{~Hz}, 1 \mathrm{H}), 3.71-3.63(\mathrm{~m}$, 2H), 2.05-1.95 (m, 2H); MS-ESI $510\left(\mathrm{M}^{+}, 3\right), 430$ (5), 269 (7), 131 (4), 91 (100).

2-[4-(3-Chlorophenylamino)-7,8-dihydro-[1,4]dioxino[2,3-g]quinazolin-7-yl]-ethanol (18a): To a solution of the 4-anilinoquinazoline $17 \mathbf{a}(0.42 \mathrm{~g}, 0.94 \mathrm{mmol})$ in $\mathrm{CH}_{2} \mathrm{Cl}_{2}(20$ $\mathrm{mL})$ was added $1 \mathrm{~N}^{-\mathrm{BBr}_{3}}(1.4 \mathrm{~mL})$ at $-30{ }^{\circ} \mathrm{C}$ and the mixture was stirred for $2 \mathrm{~h}$ at the same temperature. The reaction mixture was quenched with addition of $\mathrm{MeOH}$, and concentrated in vacuo. The residue was partitioned with $\mathrm{CH}_{2} \mathrm{Cl}_{2}$ and $2 \mathrm{~N}-\mathrm{NaOH}$ solution, and the organic layer was separated, washed with brine, dried over $\mathrm{Na}_{2} \mathrm{SO}_{4}$, and concentrated to give the alcohol 18a $(0.3 \mathrm{~g}, 75 \%):{ }^{1} \mathrm{H}-\mathrm{NMR}$ (300 MHz, DMSO-d $\left.\mathrm{d}_{6}\right) \delta 11.5(\mathrm{brs}, 1 \mathrm{H}), 8.50(\mathrm{~s}, 1 \mathrm{H}), 8.15(\mathrm{~s}$, $1 \mathrm{H}), 7.88(\mathrm{~d}, J=7.3 \mathrm{~Hz}, 1 \mathrm{H}), 7.40-7.36(\mathrm{~m}, 2 \mathrm{H}), 7.14(\mathrm{~d}, J=$ $7.5 \mathrm{~Hz}, 1 \mathrm{H}), 7.29(\mathrm{~m}, 1 \mathrm{H}), 4.78(\mathrm{~m}, 1 \mathrm{H}), 4.52-4.48(\mathrm{~m}, 2 \mathrm{H})$, $4.24(\mathrm{dd}, J=11.7,7.8 \mathrm{~Hz}, 1 \mathrm{H}), 3.66-3.63(\mathrm{~m}, 2 \mathrm{H}), 1.86-1.82$ (m, 2H).

2-[4-(3-Bromophenylamino)-7,8-dihydro-[1,4]dioxino[2,3-g]quinazolin-7-yl]-ethanol (18b): Yield: $81 \%$; ${ }^{1} \mathrm{H}-$ NMR (300 MHz, DMSO-d 6 ) $\delta 9.61$ (brs, $1 \mathrm{H}), 8.57$ (s, 1H), $8.33(\mathrm{~s}, 1 \mathrm{H}), 8.17(\mathrm{~s}, 1 \mathrm{H}), 7.98(\mathrm{~d}, J=8.4 \mathrm{~Hz}, 1 \mathrm{H}), 7.56-7.26$ $(\mathrm{m}, 3 \mathrm{H}), 4.79(\mathrm{~m}, 1 \mathrm{H}), 4.52-4.48(\mathrm{~m}, 2 \mathrm{H}), 4.24(\mathrm{dd}, J=11.7$, $7.8 \mathrm{~Hz}, 1 \mathrm{H}), 3.66-3.63(\mathrm{~m}, 2 \mathrm{H}), 1.86-1.82(\mathrm{~m}, 2 \mathrm{H})$; MS-ESI $402\left(\mathrm{M}^{+}, 100\right), 275$ (38), 251 (47), 193 (42), 114 (29), 43 (4).

2-[4-(3-Chloro-4-fluorophenylamino)-7,8-dihydro-[1,4]dioxino[2,3-g]quinazolin-7-yl]-ethanol (18c): Yield: 67\%; ${ }^{1} \mathrm{H}-\mathrm{NMR}\left(300 \mathrm{MHz}\right.$, DMSO-d $\left.{ }_{6}\right) \delta 9.62$ (brs, $\left.1 \mathrm{H}\right), 8.55$ (s, $1 \mathrm{H}), 8.30(\mathrm{dd}, J=6.9,2.4 \mathrm{~Hz}, 1 \mathrm{H}), 8.11(\mathrm{~s}, 1 \mathrm{H}), 7.92(\mathrm{~m}$, 1H), $7.49(\mathrm{t}, J=9.1 \mathrm{~Hz}, 1 \mathrm{H}), 7.27(\mathrm{~s}, 1 \mathrm{H}), 4.79(\mathrm{~m}, 1 \mathrm{H})$, 4.49-4.59 (m, 2H), 4.17 (dd, $J=11.4,7.9 \mathrm{~Hz}, 1 \mathrm{H}), 3.71(\mathrm{~m}$, 2H), $1.88(\mathrm{q}, J=6.3 \mathrm{~Hz}, 2 \mathrm{H})$; MS-ESI $375\left(\mathrm{M}^{+}, 99\right), 374$ (100), 44 (34).

2-[4-(4-Bromo-2-fluorophenylamino)-7,8-dihydro[1,4]dioxino[2,3-g]quinazolin-7-yl]-ethanol (18d): Yield: 75\%; ${ }^{1} \mathrm{H}-\mathrm{NMR}(300 \mathrm{MHz}$, DMSO-d 6 ) $\delta 9.58$ (brs, 1H), 8.39 (s, $1 \mathrm{H}), 7.96(\mathrm{~s}, 1 \mathrm{H}), 7.63(\mathrm{dd}, J=9.9,1.3 \mathrm{~Hz}, 1 \mathrm{H}), 7.44-7.54$ (m, 2H), $7.20(\mathrm{~s}, 1 \mathrm{H}), 4.71(\mathrm{~m}, 1 \mathrm{H}), 4.51-4.53(\mathrm{~m}, 2 \mathrm{H}), 4.12$ (dd, $J=11.4,7.8 \mathrm{~Hz}, 1 \mathrm{H}), 3.65(\mathrm{~m}, 2 \mathrm{H}), 1.81$ (q, $J=6.3 \mathrm{~Hz}$, 2H); MS-ESI $420\left(\mathrm{M}^{+}, 55\right), 403$ (46), 269 (88), 103 (39), 91 (76), 71 (81), 43 (100).

(4-Bromo-2-fluorophenyl)-\{7-[2-(4-methyl-piperazin1-yl)-ethyl]-7,8-dihydro-[1,4]dioxino [2,3-g] quin azolin-4yl\}-amine(3a): To a solution of 2-[4-(4-bromo-2-fluorophenylamino)-7,8-dihydro-[1,4]dioxino[2,3-g]quinazolin-7yl]-ethanol $(0.11 \mathrm{~g}, 0.26 \mathrm{mmol})$ in $\mathrm{CH}_{2} \mathrm{Cl}_{2}(10 \mathrm{~mL})$ were added $\mathrm{Et}_{3} \mathrm{~N}(0.17 \mathrm{~mL}, 1.12 \mathrm{mmol})$ and $\mathrm{MsCl}(0.043 \mathrm{~mL}$, $0.56 \mathrm{mmol}$ ) at $0{ }^{\circ} \mathrm{C}$ and the mixture was stirred for $1 \mathrm{~h}$. at room temperature. The reaction mixture was diluted with EtOAc, and washed with $0.5 \mathrm{~N}-\mathrm{NaOH}$ and brine. The organic layer was dried over $\mathrm{Na}_{2} \mathrm{SO}_{4}$ and concentrated to give a mesylate $(0.12 \mathrm{~g}, 93 \%)$ as a yellow solid, which was used for next reaction without further purification. A mixture of methanesulfonic acid 2-[4-(4-bromo-2-fluorophenylamino)-7,8-dihydro-[1,4]dioxino[2,3-g]quinazolin-7yl]-ethyl ester (55 mg, $0.13 \mathrm{mmol}$ ), 1-methyl-piperazine (1 $\mathrm{mL}$ ), and a catalytic amount of $\mathrm{NaI}$ was stirred at $80{ }^{\circ} \mathrm{C}$ for overnight. The mixture was diluted with EtOAc, and washed with sat. $\mathrm{NaHCO}_{3}$ solution and brine, and dried over $\mathrm{Na}_{2} \mathrm{SO}_{4}$ and concentrated to give 3a: Yield: 55\%; ${ }^{1} \mathrm{H}-\mathrm{NMR}$ (300 MHz, DMSO-d $\left.\mathrm{d}_{6}\right) \delta 9.50(\mathrm{brs}, 1 \mathrm{H}), 8.32(\mathrm{~s}, 1 \mathrm{H}), 7.95(\mathrm{~s}, 1 \mathrm{H})$, $7.62(\mathrm{~d}, J=9.9 \mathrm{~Hz}, 1 \mathrm{H}), 7.50(\mathrm{~m}, 1 \mathrm{H}), 7.40-7.26(\mathrm{~m}, 2 \mathrm{H})$, $7.01(\mathrm{~s}, 1 \mathrm{H}), 4.51(\mathrm{~d}, J=10.5 \mathrm{~Hz}, 1 \mathrm{H}), 4.44(\mathrm{~m}, 1 \mathrm{H}), 4.11$ (dd, $J=11.4,7.0 \mathrm{~Hz}, 1 \mathrm{H}), 2.48(\mathrm{~m}, 8 \mathrm{H}), 2.37(\mathrm{~m}, 2 \mathrm{H}), 2.24$ (s, 3H), $1.83(\mathrm{~m}, 2 \mathrm{H})$.

(4-Bromo-2-fluorophenyl)-[7-(2-morpholin-4-yl-ethyl)7,8-dihydro-[1,4]dioxino[2,3-g]quinazolin-4-yl]-amine (3b): Yield: 56\%; ${ }^{1} \mathrm{H}-\mathrm{NMR}\left(300 \mathrm{MHz}, \mathrm{DMSO}-\mathrm{d}_{6}\right) \delta 9.51$ (brs, 1H), $8.31(\mathrm{~s}, 1 \mathrm{H}), 7.95(\mathrm{~s}, 1 \mathrm{H}), 7.62(\mathrm{~d}, J=9.8 \mathrm{~Hz}, 1 \mathrm{H})$, 
$7.51(\mathrm{~m}, 1 \mathrm{H}), 7.42-7.26(\mathrm{~m}, 2 \mathrm{H}), 7.02(\mathrm{~s}, 1 \mathrm{H}), 4.51(\mathrm{~d}, J=$ $10.5 \mathrm{~Hz}, 1 \mathrm{H}), 4.42(\mathrm{~m}, 1 \mathrm{H}), 4.10(\mathrm{dd}, J=11.3,7.8 \mathrm{~Hz}, 1 \mathrm{H})$, $3.56(\mathrm{~m}, 4 \mathrm{H}), 2.47$ (m, 2H), $2.35(\mathrm{~m}, 4 \mathrm{H}), 1.82(\mathrm{~m}, 2 \mathrm{H})$.

(4-Bromo-2-fluorophenyl)-[7-(2-piperidin-4-yl-ethyl)7,8-dihydro-[1,4]dioxino[2,3-g]quinazolin-4-yl]-amine (3c): Yield: 49\%; ${ }^{1} \mathrm{H}-\mathrm{NMR}\left(300 \mathrm{MHz}, \mathrm{DMSO}-\mathrm{d}_{6}\right) \delta 9.50$ (brs, 1H), 8.31 (s, 1H), 7.96 (s, 1H), 7.62 (d, $J=9.9 \mathrm{~Hz}, 1 \mathrm{H})$, $7.53(\mathrm{~m}, 1 \mathrm{H}), 7.41-7.27(\mathrm{~m}, 2 \mathrm{H}), 7.02(\mathrm{~s}, 1 \mathrm{H}), 4.52(\mathrm{~d}, J=$ $10.5 \mathrm{~Hz}, 1 \mathrm{H}), 4.45$ (m, 1H), 4.11 (dd, $J=11.3,7.0 \mathrm{~Hz}, 1 \mathrm{H})$, $2.36(\mathrm{~m}, 2 \mathrm{H}), 2.28(\mathrm{~m}, 4 \mathrm{H}), 1.83(\mathrm{~m}, 2 \mathrm{H}), 1.72-1.50(\mathrm{~m}, 6 \mathrm{H})$.

(4-Bromo-2-fluorophenyl)-[7-(2-diethylaminoethyl)7,8-dihydro-[1,4]dioxino[2,3-g]quinazolin-4-yl]-amine (3d): Yield: 48\%; ${ }^{1} \mathrm{H}-\mathrm{NMR}$ (300 MHz, DMSO-d 6 ) $\delta 9.51$ (brs, 1H), 8.31 (s, 1H), 7.96 (s, 1H), 7.63 (d, $J=9.9 \mathrm{~Hz}, 1 \mathrm{H})$, $7.52(\mathrm{~m}, 1 \mathrm{H}), 7.39-7.25(\mathrm{~m}, 2 \mathrm{H}), 7.01(\mathrm{~s}, 1 \mathrm{H}), 4.51(\mathrm{~d}, J=$ $10.5 \mathrm{~Hz}, 1 \mathrm{H}), 4.41(\mathrm{~m}, 1 \mathrm{H}), 4.10(\mathrm{dd}, J=11.3,7.9 \mathrm{~Hz}, 1 \mathrm{H})$, 2.43 (q, $J=7.1 \mathrm{~Hz}, 4 \mathrm{H}), 2.34$ (m, 2H), 1.82 (m, 2H), 0.99 (t, $J=7.1 \mathrm{~Hz}, 6 \mathrm{H})$.

(3-Bromophenyl)-\{7-[2-(4-methyl-piperazin-1-yl)-ethyl]7,8-dihydro-[1,4]dioxino[2,3-g]quinazolin-4-yl\}-amine (3e): Yield: $42 \%$; ${ }^{1} \mathrm{H}-\mathrm{NMR}\left(300 \mathrm{MHz}, \mathrm{DMSO}-\mathrm{d}_{6}\right) \delta 9.50$ (brs, $1 \mathrm{H}), 8.48$ (s, 1H), 8.26 (s, 1H), 8.10 (s, 1H), 7.91 (d, $J=7.1$ $\mathrm{Hz}, 1 \mathrm{H}), 7.34-7.16(\mathrm{~m}, 3 \mathrm{H}), 4.50(\mathrm{~d}, J=10.3 \mathrm{~Hz}, 1 \mathrm{H}), 4.39$ (m, 1H), $4.11(\mathrm{dd}, J=11.4,7.9 \mathrm{~Hz}, 1 \mathrm{H}), 2.47(\mathrm{~m}, 8 \mathrm{H}), 2.37$ $(\mathrm{m}, 2 \mathrm{H}), 2.25(\mathrm{~s}, 3 \mathrm{H}), 1.82(\mathrm{~m}, 2 \mathrm{H})$; MS-ESI $484\left(\mathrm{M}^{+}, 16\right)$, 415 (16), 113 (100), 84 (72), 70 (99).

(3-Bromophenyl)-[7-(2-morpholin-4-yl-ethyl)-7,8-dihydro-[1,4]dioxino[2,3-g]quinazolin-4-yl]-amine (3f): Yield: $61 \%$; ${ }^{1} \mathrm{H}-\mathrm{NMR}\left(300 \mathrm{MHz}, \mathrm{DMSO}-\mathrm{d}_{6}\right) \delta 9.51$ (brs, $1 \mathrm{H}), 8.48(\mathrm{~s}, 1 \mathrm{H}), 8.25$ (s, 1H), 8.09 (s, 1H), 7.91 (d, $J=7.1$ $\mathrm{Hz}, 1 \mathrm{H}), 7.34-7.17$ (m, 3H), 4.51 (d, $J=10.5 \mathrm{~Hz}, 1 \mathrm{H}), 4.39$ $(\mathrm{m}, 1 \mathrm{H}), 4.10(\mathrm{dd}, J=11.4,7.9 \mathrm{~Hz}, 1 \mathrm{H}), 3.56(\mathrm{~m}, 4 \mathrm{H}), 2.48$ (m, 2H), $2.37(\mathrm{~m}, 4 \mathrm{H}), 1.83(\mathrm{~m}, 2 \mathrm{H})$.

(3-Bromophenyl)-[7-(2-piperidin-4-yl-ethyl)-7,8-dihydro-[1,4]dioxino[2,3-g]quinazolin-4-yl]-amine (3g): Yield: $65 \%$; ${ }^{1} \mathrm{H}-\mathrm{NMR}\left(300 \mathrm{MHz}, \mathrm{DMSO}-\mathrm{d}_{6}\right) \delta 9.58$ (brs, $1 \mathrm{H}), 8.50$ (s, 1H), 8.26 (s, 1H), 8.11 (s, 1H), 7.94 (d, $J=7.1$ $\mathrm{Hz}, 1 \mathrm{H}), 7.39-7.20(\mathrm{~m}, 3 \mathrm{H}), 4.52$ (d, $J=10.5 \mathrm{~Hz}, 1 \mathrm{H}), 4.48$ $(\mathrm{m}, 1 \mathrm{H}), 4.11(\mathrm{dd}, J=11.4,7.9 \mathrm{~Hz}, 1 \mathrm{H}), 2.37(\mathrm{~m}, 2 \mathrm{H}), 2.28$ $(\mathrm{m}, 4 \mathrm{H}), 1.84(\mathrm{~m}, 2 \mathrm{H}), 1.72-1.49(\mathrm{~m}, 6 \mathrm{H})$.

2-[\{2-[4-(3-Bromophenylamino)-7,8-dihydro-[1,4]dioxino [2,3-g]quinazolin-7-yl]-ethyl\}-(2-hydroxy-ethyl)amino]-ethanol (3h): Yield: 56\%; ${ }^{1} \mathrm{H}-\mathrm{NMR}(300 \mathrm{MHz}$, DMSO-d $\left._{6}\right) \delta 9.53$ (brs, $\left.1 \mathrm{H}\right), 8.51(\mathrm{~s}, 1 \mathrm{H}), 8.28(\mathrm{~s}, 1 \mathrm{H}), 8.10$ $(\mathrm{s}, 1 \mathrm{H}), 7.94(\mathrm{~d}, J=7.1 \mathrm{~Hz}, 1 \mathrm{H}), 7.39-7.21(\mathrm{~m}, 3 \mathrm{H}), 4.52(\mathrm{~d}$, $J=10.5 \mathrm{~Hz}, 1 \mathrm{H}), 4.48(\mathrm{~m}, 1 \mathrm{H}), 4.11(\mathrm{dd}, J=11.4,7.9 \mathrm{~Hz}$, 1H), 3.49 (m, 4H), 2.59 (m, 4H), 2.49 (m, 2H), 1.82 (m, 2H).

(3-Bromophenyl)-[7-(2-pyrrolidin-1-yl-ethyl)-7,8-dihydro-[1,4]dioxino[2,3-g]quinazolin-4-yl]-amine (3i): Yield: $68 \%$; ${ }^{1} \mathrm{H}-\mathrm{NMR}\left(300 \mathrm{MHz}, \mathrm{DMSO}^{-\mathrm{d}_{6}}\right) \delta 9.52$ (brs, $1 \mathrm{H}), 8.50(\mathrm{~s}, 1 \mathrm{H}), 8.27$ (s, 1H), $8.11(\mathrm{~s}, 1 \mathrm{H}), 7.94$ (d, $J=7.1$ $\mathrm{Hz}, 1 \mathrm{H}), 7.36-7.20(\mathrm{~m}, 3 \mathrm{H}), 4.51(\mathrm{~d}, J=10.5 \mathrm{~Hz}, 1 \mathrm{H}), 4.42$ (m, 1H), $4.11(\mathrm{dd}, J=11.4,7.9 \mathrm{~Hz}, 1 \mathrm{H}), 2.62(\mathrm{~m}, 2 \mathrm{H}), 2.48$ (m, 4H), $1.85(\mathrm{~m}, 2 \mathrm{H}), 1.69(\mathrm{~m}, 4 \mathrm{H})$.

(3-Chlorophenyl)-\{7-[2-(4-methyl-piperazin-1-yl)-ethyl]-7,8-dihydro-[1,4]dioxino[2,3-g]quinazolin-4-yl\}-amine (3j): Yield: 55\%; ${ }^{1} \mathrm{H}-\mathrm{NMR}\left(300 \mathrm{MHz}, \mathrm{DMSO}-\mathrm{d}_{6}\right) \delta 9.55$ (brs, 1H), $8.51(\mathrm{~s}, 1 \mathrm{H}), 8.16(\mathrm{~s}, 1 \mathrm{H}), 8.11(\mathrm{~s}, 1 \mathrm{H}), 7.80(\mathrm{~d}, J=$ $7.1 \mathrm{~Hz}, 1 \mathrm{H}), 7.42-7.34(\mathrm{~m}, 2 \mathrm{H}), 7.14$ (d, $J=8.0 \mathrm{~Hz}, 1 \mathrm{H})$, $4.53(\mathrm{~d}, J=10.5 \mathrm{~Hz}, 1 \mathrm{H}), 4.49(\mathrm{~m}, 1 \mathrm{H}), 4.11(\mathrm{dd}, J=11.4$, $7.9 \mathrm{~Hz}, 1 \mathrm{H}), 2.47(\mathrm{~m}, 8 \mathrm{H}), 2.37$ (m, 2H), 2.25 (s, 3H), 1.82 (m, 2H).

(3-Chlorophenyl)-[7-(2-morpholin-4-yl-ethyl)-7,8-dihydro-[1,4]dioxino[2,3-g]quinazolin-4-yl]-amine (3k): Yield: 56\%; ${ }^{1} \mathrm{H}-\mathrm{NMR}\left(300 \mathrm{MHz}, \mathrm{DMSO}-\mathrm{d}_{6}\right) \delta 9.53$ (brs, $1 \mathrm{H}), 8.50(\mathrm{~s}, 1 \mathrm{H}), 8.16(\mathrm{~s}, 1 \mathrm{H}), 8.10(\mathrm{~s}, 1 \mathrm{H}), 7.86(\mathrm{~d}, J=8.0$ $\mathrm{Hz}, 1 \mathrm{H}), 7.36(\mathrm{t}, J=8.0 \mathrm{~Hz}, 1 \mathrm{H}), 7.32(\mathrm{~m}, 1 \mathrm{H}), 7.10(\mathrm{~d}, J=$ $8.0 \mathrm{~Hz}, 1 \mathrm{H}), 4.53(\mathrm{~d}, J=10.5 \mathrm{~Hz}, 1 \mathrm{H}), 4.38(\mathrm{~m}, 1 \mathrm{H}), 4.11$ (dd, $J=11.3,7.9 \mathrm{~Hz}, 1 \mathrm{H}), 3.59(\mathrm{~m}, 4 \mathrm{H}), 2.39-2.33(\mathrm{~m}, 6 \mathrm{H})$, $1.83(\mathrm{~m}, 2 \mathrm{H})$.

(3-Chlorophenyl)-[7-(2-piperidin-4-yl-ethyl)-7,8-dihydro-[1,4]dioxino[2,3-g]quinazolin-4-yl]-amine (3l): Yield: 57\%; ${ }^{1} \mathrm{H}-\mathrm{NMR}\left(300 \mathrm{MHz}, \mathrm{DMSO}-\mathrm{d}_{6}\right) \delta 9.54$ (brs, $1 \mathrm{H}), 8.50$ (s, 1H), 8.17 (s, 1H), $8.11(\mathrm{~s}, 1 \mathrm{H}), 7.85$ (d, $J=7.4$ $\mathrm{Hz}, 1 \mathrm{H}), 7.37-7.32(\mathrm{~m}, 2 \mathrm{H}), 7.12(\mathrm{~d}, J=8.0 \mathrm{~Hz}, 1 \mathrm{H}), 4.52$ $(\mathrm{d}, J=10.5 \mathrm{~Hz}, 1 \mathrm{H}), 4.48(\mathrm{~m}, 1 \mathrm{H}), 4.10(\mathrm{dd}, J=11.3,7.9$ $\mathrm{Hz}, 1 \mathrm{H}), 2.36(\mathrm{~m}, 2 \mathrm{H}), 2.28(\mathrm{~m}, 4 \mathrm{H}), 1.82(\mathrm{~m}, 2 \mathrm{H}), 1.73-$ $1.48(\mathrm{~m}, 6 \mathrm{H})$.

(3-Chlorophenyl)-[7-(2-diethylaminoethyl)-7,8-dihydro[1,4]dioxino[2,3-g]quinazolin-4-yl]-amine (3m): Yield: $56 \%$; ${ }^{1} \mathrm{H}-\mathrm{NMR}\left(300 \mathrm{MHz}, \mathrm{DMSO}-\mathrm{d}_{6}\right) \delta 9.54$ (brs, $\left.1 \mathrm{H}\right), 8.51$ $(\mathrm{s}, 1 \mathrm{H}), 8.16(\mathrm{~s}, 1 \mathrm{H}), 8.10(\mathrm{~s}, 1 \mathrm{H}), 7.86(\mathrm{~d}, J=8.0 \mathrm{~Hz}, 1 \mathrm{H})$, 7.36-7.32 (m, 2H), $7.10(\mathrm{~d}, J=8.0 \mathrm{~Hz}, 1 \mathrm{H}), 4.52(\mathrm{~d}, J=10.5$ $\mathrm{Hz}, 1 \mathrm{H}), 4.38$ (m, 1H), 4.11 (dd, $J=11.3,7.9 \mathrm{~Hz}, 1 \mathrm{H}), 2.42$ (q, $J=7.1 \mathrm{~Hz}, 4 \mathrm{H}), 2.36(\mathrm{~m}, 2 \mathrm{H}), 1.83(\mathrm{~m}, 2 \mathrm{H}), 0.96(\mathrm{t}, J=$ $7.1 \mathrm{~Hz}, 6 \mathrm{H})$.

(3-Chlorophenyl)-[7-(2-pyrrolidin-1-yl-ethyl)-7,8-dihydro-[1,4]dioxino[2,3-g]quinazolin-4-yl]-amine (3n): Yield: 68\%; ${ }^{1} \mathrm{H}-\mathrm{NMR}\left(300 \mathrm{MHz}, \mathrm{DMSO}-\mathrm{d}_{6}\right) \delta 9.53$ (brs, $1 \mathrm{H}), 8.50$ (s, 1H), 8.16 (s, 1H), $8.10(\mathrm{~s}, 1 \mathrm{H}), 7.86$ (d, $J=7.9$ $\mathrm{Hz}, 1 \mathrm{H}), 7.37-7.33$ (m, 2H), 7.10 (d, $J=7.9 \mathrm{~Hz}, 1 \mathrm{H}), 4.50$ $(\mathrm{d}, J=10.5 \mathrm{~Hz}, 1 \mathrm{H}), 4.43(\mathrm{~m}, 1 \mathrm{H}), 4.10(\mathrm{dd}, J=11.4,7.9$ $\mathrm{Hz}, 1 \mathrm{H}), 2.62(\mathrm{~m}, 2 \mathrm{H}), 2.47$ (m, 4H), 1.83 (m, 2H), 1.70 (m, $4 \mathrm{H})$.

(3-Chloro-4-fluorophenyl)-\{7-[2-(4-methyl-piperazin1-yl)-ethyl]-7,8-dihydro-[1,4]dioxino[2,3-g]quinazolin-4yl\}-amine (3o): Yield: 55\%; ${ }^{1} \mathrm{H}-\mathrm{NMR}$ (300 MHz, DMSO$\left.\mathrm{d}_{6}\right) \delta 9.58(\mathrm{brs}, 1 \mathrm{H}), 8.49(\mathrm{~s}, 1 \mathrm{H}), 8.25(\mathrm{dd}, J=6.9,2.6 \mathrm{~Hz}$, $1 \mathrm{H}), 8.09(\mathrm{~s}, 1 \mathrm{H}), 7.86(\mathrm{~m}, 1 \mathrm{H}), 7.43(\mathrm{t}, J=9.1 \mathrm{~Hz}, 1 \mathrm{H}), 7.21$ $(\mathrm{s}, 1 \mathrm{H}), 4.52(\mathrm{~d}, J=10.6 \mathrm{~Hz}, 1 \mathrm{H}), 4.39(\mathrm{~m}, 1 \mathrm{H}), 4.11(\mathrm{dd}, J=$ 11.4, 7.9 Hz, 1H), $2.49(\mathrm{~m}, 8 \mathrm{H}), 2.37$ (m, 2H), $2.24(\mathrm{~s}, 3 \mathrm{H})$, 1.86 (m, 2H); MS-ESI $458\left(\mathrm{M}^{+}, 19\right), 276$ (21), 152 (20), 113 (89), 70 (52), 40 (100).

(3-Chloro-4-fluorophenyl)-[7-(2-morpholin-4-yl-ethyl)7,8-dihydro-[1,4]dioxino[2,3-g]quinazolin-4-yl]-amine (3p): Yield: 66\%; ${ }^{1} \mathrm{H}-\mathrm{NMR}\left(300 \mathrm{MHz}, \mathrm{DMSO}-\mathrm{d}_{6}\right) \delta 9.62$ (brs, 1H), 8.50 (s, 1H), 8.24 (dd, $J=6.9,2.6 \mathrm{~Hz}, 1 \mathrm{H}), 8.09$ (s, 1H), $7.93(\mathrm{~m}, 1 \mathrm{H}), 7.44(\mathrm{t}, J=9.1 \mathrm{~Hz}, 1 \mathrm{H}), 7.27(\mathrm{~s}, 1 \mathrm{H})$, $4.58(\mathrm{~d}, J=10.5 \mathrm{~Hz}, 1 \mathrm{H}), 4.45(\mathrm{~m}, 1 \mathrm{H}), 4.18(\mathrm{dd}, J=11.3$, $7.8 \mathrm{~Hz}, 1 \mathrm{H}), 3.65$ (m, 4H), $2.56(\mathrm{~m}, 2 \mathrm{H}), 2.46$ (m, 4H), 1.92 (m, 2H).

(3-Chloro-4-fluorophenyl)-[7-(2-piperidin-4-yl-ethyl)7,8-dihydro-[1,4]dioxino[2,3-g]quinazolin-4-yl]-amine (3q): Yield: 62\%; ${ }^{1} \mathrm{H}-\mathrm{NMR}\left(300 \mathrm{MHz}, \mathrm{DMSO}-\mathrm{d}_{6}\right) \delta 9.62$ 
(brs, 1H), 8.50 (s, 1H), 8.24 (dd, $J=6.9,2.6 \mathrm{~Hz}, 1 \mathrm{H}), 8.09$ $(\mathrm{s}, 1 \mathrm{H}), 7.93(\mathrm{~m}, 1 \mathrm{H}), 7.44(\mathrm{t}, J=9.1 \mathrm{~Hz}, 1 \mathrm{H}), 7.27(\mathrm{~s}, 1 \mathrm{H})$, $4.52(\mathrm{~d}, J=11.0 \mathrm{~Hz}, 1 \mathrm{H}), 4.48(\mathrm{~m}, 1 \mathrm{H}), 4.14(\mathrm{dd}, J=11.4$, $6.9 \mathrm{~Hz}, 1 \mathrm{H}), 2.36(\mathrm{~m}, 2 \mathrm{H}), 2.28(\mathrm{~m}, 4 \mathrm{H}), 1.83(\mathrm{~m}, 2 \mathrm{H}), 1.72-$ $1.50(\mathrm{~m}, 6 \mathrm{H})$.

Acknowledgments. This work is supported in part by a grant for the anti-cancer research program from Korea Research Institute of Chemical Technology.

\section{References}

1. Ciardiello, F.; Tortora, G. Clin. Cancer Res. 2001, 7, 2958.

2. Woodburn, J. R. Pharmacol. Ther 1999, 82, 241.

3. (a) Fry, D. W.; Kraker, A. J.; McMichael, A.; Ambroso, L. A.; Nelson, J. M.; Leopold, W. R.; Conners, R. W.; Bridges, A. J. Science 1994, 265, 1093. (b) Tsou, H.-R.; Mamuya, N.; Johnson, B. D.; Reich, M. F.; Gruber, B. C.; Ye, F.; Nilakanta, R.; Shen, R.; Discafani, C.; DeBlanc, R.; Davis, R.; Koehn, F. E.; Greenberger, L. M.; Wang, Y.-F.; Wissner, A. J. Med. Chem. 2001, 44, 2719. (c) Bridges, A. J.; Zhou, H.; Cody, D. R.; Rewcastle, G. W.; McMichael, A.; Showalter, H. D. H.; Fry, D. W.; Kraker, A. J.; Denny, W. A. J. Med. Chem. 1996, 39, 267. (d) Myers, M. R.; Setzer, N. N.; Spada, A. P.; Zulli, A. L.; Hsu, C. J.; Zilberstein, A.; Johnson, S. E.; Hook, L. E.; Jacoski, M. V. Bioorg. Med. Chem. Lett. 1997, 7, 417. (e) Wissner, A.; Berger, D. M.; Boschelli, D. H.; Floyd, M. B. Jr.,; Greenberger, L. M.; Gruber, B. C.; Johnson, B. D.; Mamuya, N.; Nilakantan, R.; Reich, M. F.; Shen, R.; Tsou, H.-R.; Upeslacis, E.; Wang, Y. F.; Wu, B.; Ye, F.; Zhang, N. J. Med. Chem. 2000, 43, 3244.

4. Barker, A. J.; Gibson, K. H.; Grundy, W.; Godfrey, A. A.; Barlow, J. J.; Healy, M. P.; Woodburn, J. R.; Ashton, S. E.; Curry, B. J.; Scarlett, L.; Henthorn, L.; Richards, L. Bioorg. Med. Chem. Lett.
2001, 11, 1911.

5. Ciardiello, F.; Caputo, R.; Bianco, R.; Damiano, V.; Pomatico, G. De Placido, S.; Bianco, A. R.; Tortora, G. Clin. Cancer Res. 2000, 6, 2053.

6. A similar structure for $[1,4]$-dioxino quinazoline is known in the literatures; (a) Lee, J. Y.; Park, Y. K.; Seo, S. H.; So, I.-S.; Chung, H.-K.; Yang, B.-S.; Lee, S. J.; Park, H.; Lee, Y. S. Arch. Pharm. Pharm. Med. Chem. 2001, 334, 357. (b) Lee, J. Y.; Park, Y. K.; Seo, S. H.; Yang, B.-S.; Park, H.; Lee, Y. S. Arch. Pharm. Pharm. Med. Chem. 2002, 10, 487.

7. (a) Bertram, G.; Scherer, A.; Steglich, W.; Weber, W.; Anke, T. Tetrahedron Lett. 1996, 44, 7955. (b) Ganesh, T.; Sharma, K. K.; Krupadanam, G. L. D. Bull. Chem. Soc. Jpn. 2001, 74, 2397. (c) Pearl, I. A.; Beyer, D. L. J. Am. Chem. Soc. 1953, 75, 2627.

8. For alkylation of unsubstituted catechol: (a) Procopiou, P. A.; Cherry, P. C.; Deal, M. J.; Lamont, B. J. Chem. Soc. Perkin Trans. 1 1994, 1773. (b) Procopiou, P. A.; Brodie, A. C.; Deal, M. J.; Hayman, D. F. Tetrahedron Lett. 1993, 34, 7483.

9. (a) Ha, J. D.; Shin, E. Y.; Chung, Y.; Choi, J.-K. Bull. Korean Chem. Soc. 2003, 24, 1567. (b) Ha, J. D.; Kang, S. K.; Cheon, H.G.; Choi, J.-K. Bull. Korean Chem. Soc. 2004, 25, 1784.

10. For alkylation of phenol with epoxide: (a) Hou, X.-L.; Li, B.-F.; Dai, L.-X. Tetrahedron: Asymmetry 1999, 10, 2319. (b) Kitaori, K.; Frukawa, Y.; Yoshimoto, H.; Otera, J. Tetrahedron 1999, 55, 14381. (c) McClure, D. E.; Arison, B. H.; Baldwin, J. J. J. Am. Chem. Soc. 1979, 101, 3666.

11. Wright, S. W.; Carlo, A. A.; Cartu, M. D.; Danley, D. E.; Hageman, D. L.; Karam, G. A.; Levy, C. B.; Mansour, M. N.; Mathiowetz, A. M.; McClure, L. D.; Nestor, N. B.; McPherson, R. K.; Pandit, J.; Pustilnik, L. R.; Schulte, G. K.; Soeller, W. C.; Treadway, J. L.; Wang, I.-K.; Bauer, P. H. J. Med. Chem. 2002, 45, 3865.

12. Li, B.; Chang, C. M.; Yuan, M.; McKenna, W. G.; Shu, H. K. Cancer Res. 2003, 63, 7443. 